\title{
Outlook on Student Retention in Higher Education University Reforms in Morocco
}

\author{
Zoulal Mansouri (Corresponding author) \\ The Moroccan American Studies Laboratory (MAS), Ben M'Sik Faculty of Letters \& Human Sciences, Hassan II University of Casablanca, Morocco \\ E-mail: mansourizoulal@gmail.com \\ Mohamed El Amine Moumine \\ Ben M'Sik Faculty of Letters and Human Sciences, Hassan II University of Casablanca, Morocco \\ E-mail: moumineamine@gmail.com
}

Received: 12-03-2017

Accepted: 22-04-2017

Published: 30-04-2017

doi:10.7575/aiac.ijels.v.5n.2p.53

URL: http://dx.doi.org/10.7575/aiac.ijels.v.5n.2p.53

\begin{abstract}
High student attrition rates at university have become one of the most challenging issues in higher education worldwide in the last five decades. Moroccan universities are no exception. At-risk students drop out of studies for a plethora of reasons, and the attrition rate is increasing despite the efforts made in education reforms carried out since 1999. This article reviews the most important components of the higher education reforms that have been adopted in Moroccan higher education in their endeavor to enhance student retention in university. These components are chronologically reviewed, first in the National Charter of Education and Training (NCET) launched in 1999, second in the Emergency Plan conducted in 2009-2012, and finally in the latest Strategic Vision of Reform 2015-2030. It is concluded that more efforts are necessary to strike a balance between quantity and quality in terms of student retention in university education.
\end{abstract}

Keywords: admission capacity, attrition, open-admission institutions, student support, university reform.

\section{Introduction}

According to the latest report of the World Economic Forum on human capital, Morocco is ranked 98th out of 130 countries studied. With an unemployment rate of one-third of the population, Morocco is ranked $104^{\text {th }}$ in the $15-24$ age group, and $113^{\text {th }}$ in the 25-54 age group (World Economic Forum, 2016, p.24). This is mainly due to illiteracy, and to the high rates of attrition among university students, namely repetitions and dropouts (UNESCO, 2015). Indeed, the Moroccan higher education system does not succeed in retaining students to degree completion. According to the latest study of the Higher Council for Education, Training and Scientific Research, 64 per cent of students drop out of university without a degree, 25.2 per cent of these occurring in the first year, 40.2 per cent after two years of studies, and 21.9 per cent after three years in university. Among the students who persist, many spend up to six years in university without completing their degree (CSEFRS, 2014, p.103).

The purpose of this article is to review the most important components of the higher education reforms adopted in university education in its struggle against student attrition at university. This review is done chronologically, based mainly on the Ministry of Higher Education's official documents (1999-2014), and those of the Higher Council for Education (2000-2015). First, it describes briefly the most relevant components to student retention that were introduced in the 1999 Reform, namely the National Charter of Education and Training (NCET, 1999). Second, it explains further the actions undertaken in the Emergency Plan (2009-2012), with a particular focus on its achievements and limitations. Finally, it highlights the most recent innovative recommendations presented by the Higher Council for Education in the new 2015-2030 Strategic Vision of Reform (CSEFRS, 2015) in terms of university student retention.

\section{The National Charter of Education and Training (NCET)}

Upon accession to the throne in 1999, His Majesty the King Mohammed VI asserted that only 'human capital is the lever of development and the source of wealth. It is also the vehicle for the transformation and management of other resources and their integration into the development process' (Royal speech, 30 $0^{\text {th }}$ July, 2000, p.34). This human capital could only be developed through education, to the point of declaring education and training 'the first national priority, after territorial integrity', and the decade 2000-2009 a 'national decade of education' (NCET, 1999, articles 20-21). Since then, the education system in general and higher education in particular have undergone profound changes.

\subsection{Background and structure of the NCET}

The 1999 education reform project, known as the NCET, was prepared by the Special Education and Training Commission, and was set up by a national consensus that transcended all political divisions (Lamrini, 2007, p.12). The 
NCET is composed of two parts. The first consists of the constitutional dimension relating to the constant foundations of the education and training system, its major objectives, the rights and duties of individuals and communities, as well as the mobilization of the entire nation for the success of the reform. The second part, considered innovative and qualitative, identifies six areas of innovation outlined in 19 levers of change. They focus on 'the extension of education and its connection with the economic environment, on the new pedagogical architecture, on education and training quality improvement, on human resources, on governance, and finally on partnership and funding' (NCET, 1999, pp.25).

One of the major contributions of the NCET is the drafting of Law 01-00 on the organization of higher education, which officially came into force on $3^{\text {rd }}$ March, 2000. For the first time, 'the education and training system will be subject, in its entirety, to a regular evaluation of both its internal and external achievements, which affect all the pedagogic and administrative areas' (NCET, 1999, art. 157). In the NCET, the higher education reform 'includes universities, institutions, specialized affiliated faculties, engineering schools that were preceded by preparatory classes, schools and higher institutes, institutions for academic staff and training, and specialized technician's training or equivalent'(NCET, 1999, art.77).

Two strong decisions distinguished the 1999 reform. First, the university was given a bigger financial and academic autonomy (NCET, art.150). Second, the higher education system adopted a new pedagogic 'cycle structure', which emphasized a progressive overhaul of the whole system in order to ensure better quality. Henceforth, the university studies' structure has become composed of a first cycle, a second cycle, and a doctoral cycle (NCET, art.78-81). In prospect of making the Moroccan education system more visible and in line with modern international systems, particularly the European model, the higher education system has been aligned with the Bologna process and engaged in the quality assurance approach adopted by European universities.

\subsection{Pedagogical cycles and alignments with international standards}

The academic year 2003-2004 was marked by the introduction of a new pedagogical architecture, namely 'Licence, Master, Doctorat' (LMD), designed according to the orientations of the Bologna process. Although it was never mentioned in the NCET, the LMD system is considered to be the core of the new academic reform, and was applied in limited admission institutions in 2006-2007 (MENESFCRS, 2006, p. 3). Quality assurance laid the foundation for 'establishing the accreditation of all majors in public and private higher education; establishing an evaluation system; and creating an authority of the system's evaluation and regulation' (p.8). This combination of the Moroccan and foreign systems enabled education policymakers to develop several cooperative projects with European universities, notably within the TEMPUS program, which aims to promote quality assurance, professional training development, the use of ICT, and support for university governance, etc. (MENESFCRS, Sep, 2014).

In this phase of the reform (2000-2007), 30 faculties and higher institutions (meaning colleges and institutions at the university level) were created in different geographic parts of Morocco, 13 of which are open admission institutions and 17 of which are limited admission institutions that are highly selective and subject to specific admission requirements (MENESFCRS, 2008, p.92). This made the number of students in both public and private institutions rise from 296,000 in 1999-2000 to 370,000 in 2006-2007, representing an average annual growth rate of 3.2 per cent. However, these new institutions did not meet the need of a significant increase in the number of baccalaureate degree holders, which made education policymakers, who did not plan for this increasing demand, face the challenge of the university admission capacity limitation, and consequently the first year students' desired orientation.

Despite an increase of 47 per cent in the number of students enrolled in science and technology majors at limited admission institutions since 2000-2001, as advocated by the NCET, (MENESFCRS, 2008, p.93), a majority of 89 per cent of the students were still enrolled in open admission institutions in 2006-2007, with 80 per cent in literature and social sciences (p.101). The impact of this unbalanced orientation was reflected in the high percentage (78 per cent) of students graduating in literature and social sciences studies (CSEFRS, 2008, V2, p.36). Paradoxically, these studies which students apparently prefer 'do not provide a training offer adapted enough to the needs of the labor market' (CSEFRS, 2008, V2, p.101). In 2002, the unemployment rate among graduates from limited admission institutions was about 4.5 per cent, compared with 18.6 per cent among graduates from specialized institutions and 40.4 per cent among open admission faculty graduates (p.102).

Indeed, despite the implementation of the NCET, higher education was far from meeting the expectations and the growing needs of a Moroccan economy engaged in major industrial projects (MENESFCRS, 2011, p.4). The danger of the quantitative policy over the qualitative one in higher education has been decried at the State's highest level:

(.....) Certainly, many steps have been undertaken successfully since the launch, three years ago, of this difficult but vital project. Nevertheless, the quantitative aspect predominates in what has been achieved. Combined with the absence of bold and resolute decisions requiring an in-depth reform of the very essence of the education and training system, this leads us to say on behalf of the Nation: Enough of an Education generating unemployment and ostracism! (Royal speech, 30 ${ }^{\text {th }}$ July 2003, p.77).

In addition to graduates' unemployment rates, higher education was still trapped in the university attrition phenomenon, with an average annual repetition rate of 17 per cent in all majors, and an average repetition rate of 30 per cent in open 
admission institutions (MENESFCRS, 2008, p.108). Several reports have identified the recurring dysfunctions in the education system in general and that of higher education in particular. Nationally, the 50-year report on human development in Morocco (Rapport général, 2005), as well as the analytical report of the National Authority of Evaluation (CSEFRS, 2008), highlighted the challenges facing higher education in general and university education in particular.

While the Moroccan education system was engaging in the reform implementation, international reports highlighted its failure. For example, the Global Poverty Report found that the percentage of the Moroccan population living below the poverty line constituted 20-25 per cent, 2.5 per cent of which were children-mostly girls without schooling in rural areas (Banque Mondiale, 2007). This report by the United Nations Human Development Program ranked Morocco $126^{\text {th }}$ out of 177 countries studied because of the alarming illiteracy rates (52.3 per cent) among young people aged 15-24 years who should at this age be at school or university (PNUD, 2007). The World Bank report on education in Morocco was not any better. Compared to the countries of the Middle East and North Africa region (MENA), Morocco was ranked $11^{\text {th }}$ out of 14 countries studied just before Yemen, Djibouti and Iraq, which were in a state of war (Banque Mondiale, 2008).

Further to the Moroccan education system's failure, its performance and quality were once again decried at the highest level of the State. At the 2007 autumn parliament-opening session, His Majesty the King urged the new government to reconsider the reform of education in depth, in line with the guidelines of the NCET and in coordination with the Higher Council for Education. His Majesty ordered the government 'to start without delay the implementation of an Emergency Plan to consolidate prior achievements and make the necessary adjustments, ensuring that the provisions of the NCET are applied fully'. His Majesty urged policymakers to 'bring courageous and efficient solutions to the real difficulties penalizing this vital sector, in consultation and coordination with the representative constitutional institution in this field, namely the Higher Council for Education' (Royal speech, 2007, p.145).

\section{The Emergency Plan 2009-2012}

\subsection{Admission Capacity}

The Emergency Plan was launched in 2009 in an attempt to improve the quality of education both on academic and social levels. Its application is the roadmap that universities must adapt to face the challenges of admission capacity and education quality improvement in order to meet the needs of major projects launched by the State (MENESFCRS, 2009, p.5). Thus, the Emergency Plan has the operational role of implementing and consolidating the provisions of the National Charter of Education and Training (CSEFRS, 2014, p.10). It consists of twelve projects focusing on higher education: three projects aiming to stimulate initiative and excellence, seven projects dealing with the system's transverse issues, and two projects targeting the means to success (MENESFCRS, 2009, p.8).

A mid-term assessment of the Emergency Plan showed that the university admission capacity amounted to 61,432 places in 2009-2011, 29,864 in open admission institutions, and 31,568 in limited admission institutions. 48,827 places were achieved in 2009-2011 with a completion rate of 126 per cent. In 2010-2011, the total number of places increased to 373,772 , compared with 312,340 in 2008-2009, representing an increase of 13 per cent in open admission institutions and 41 per cent in limited admission institutions. The number of new entrants to universities increased by 55 per cent compared to 2008-2009, to reach 127,818, with 67 per cent of these enrollments being in limited admission institutions. Between 2008-2009 and 2010-2011, the overall education admissions grew from 1664 to 1970 , recording an increase of 18 per cent. In 2010-2011, the number of vocational and specialised master's degrees increased by 21 per cent compared to 2009-2010 (an additional 105 per cent compared to 2008-2009) (MENESFCRS, 2011, pp.23-28).

\subsection{Linguistic Reform and academic tutoring}

In addition to improving the admission capacity and creating seven new institutions, the Emergency Plan has paid remarkable attention to student retention through the linguistic and academic tutoring support. The problem of the transition from Arabic as the language of instruction at the secondary level to French as the language of instruction in higher education has been partially solved. University syllabi included intensive French language and communication courses as well as a language positioning test in the beginning of the first year to help students improve their linguistic competence (MENESFCRS, 2011, p.31). As well, a major linguistic event occurred in the history of education in Morocco during this phase. In 2006, 'Amazigh' studies were launched in university at the bachelor's and master's levels, finally meeting a long-lasting demand of the 'Amazigh' population of Morocco.

Similarly, for the first time, academic and psychosocial tutoring was introduced in university as a means of support to students at risk of dropping out of university (Emergency Plan, 2009-2012, project 13). Academic tutoring concerns pedagogical and methodological issues, and psychosocial tutoring involves tutors in helping the students with personal difficulties. The tutors are usually volunteer master's or doctoral students. This experience began very timidly, as evidenced by the number of students benefiting from this support, increasing from 1 per cent in 2008-2009 to 21 per cent in 2009-2010, to 30 per cent in 2010-2011. Even though only five universities carried out this experience with more than 50 per cent of beneficiaries, the share of beneficiaries per university varied between 11 per cent and 100 per cent depending on the universities that adopted the tutoring system (MENESFCRS, 2011, p.30).

\subsection{Social Structures}

The NCET admitted the necessity of improving 'the social and material conditions of learners and caring for individuals with special needs' (NCET, 1999, Lever.14). Following this recommendation, the government signed 17 development contracts with 15 universities, and the 'Office National des Euvres Universitaires Sociales et Culturelles' (ONOUSC) 
was created. It was established in 2001 as a public institution with legal status and financial autonomy. It is responsible for providing students with accommodation, food services, health coverage, and grant services, as well as cultural and sports activities (CSEFRS, 2014, p.41). Thus, 180,000 grants were planned to be provided to students in 2012, an increase of 65 per cent compared to 2008 (MENESFCRS, 2009, p.12).

In 2000-2008, only 34,000 students benefited from university residence halls and boarding school services (MENESFCRS, 2009, p.9). In this regard, the Emergency Plan projects have improved the students' social support system by creating new residence halls. In collaboration with the private sector, this operation planned to reach 15,400 additional beds by 2012, a growth rate of 50 per cent. More than 5.5 million meals were served in 2012, representing an increase of 90 per cent compared to 2008. However, despite this progress, the 'massification' that universities are undergoing hinders the expansion of the increasing accommodation demand (CSEFRS, 2014, p.42).

In general, efforts to improve the quality of education, from the academic to the social structures, with the aim of reducing student attrition have had a positive impact on students' internal and external achievements. Within one year, the dropout rate of students in the first year of 'Licence,' decreased by 4 points. It dropped from 22 per cent in 2008-09 to 18 per cent in 2009-2010, with the lowest attrition rate in Faculties of Sciences (-4.4 points), and the highest in Faculties of Law, Economics and Social Sciences, with a decrease of 3.6 points (MENESFCRS, 2011, p.34).

The overall graduation rate exceeded the 50 per cent that was estimated by the Emergency Plan, and the best results were obtained in science and technology majors. In 2009-2010, awards of excellence students received amounted to 2348, representing an increase of 120 per cent compared to 2008-09. They covered students from all universities and all degrees, as well as all aspects of student life, including academic, artistic, cultural and sports activities (MENESFCRS, 2011, pp.35-36). In terms of graduates' employability, pilot experiments were undertaken at some universities to enhance students' job searches or develop their 'entrepreneurial' projects, but they were not integrated in an overall employability policy (p. 58), and no studies have been conducted yet to show for their utility. Nevertheless, despite all the academic and social improvements achieved in the Emergency Plan in terms of the quantity and quality, the latter has had many shortcomings.

\subsection{The Emergency Plan's shortcomings}

\subsubsection{Admission Capacity}

The implementation of the Emergency Plan during 2009-2012 was budgeted at 12.6 billion MAD, 8.2 billion MAD of which was for operational needs (excluding salaries), and 4.4 billion MAD of which was for investments. It should be noted that the highest budget was allocated to improving the extension of higher education requirements, at 62 per cent, with 17 per cent going towards improving admissions and social services (MENSFCRS, 2009, p. 18). Therefore, in 2001-2013, the number of university students rose from 261,629 to 543,419 mainly in open admission institutions. The latter absorb 86.7 per cent of the total number of university students. Limited admission enrollments increased from 8 per cent in 2001 to 13.3 per cent in 2013 (CSEFRS, 2014, p.101).

As regards admission capacity and financial support, inequalities and disparities have been recorded between the open and limited admission systems. Despite an increase of 30,000 places at open admission institutions in 2009-2013, the admission capacity was insufficient and could not meet the growing social demand. Only 67,135 places were available instead of 112,000 places, as estimated in the Emergency Plan. Furthermore, the admission rate in the two systems has generally remained unbalanced, with a staggering 175 per cent in the open admission system compared to 63 per cent in the limited admission system. In other words, the system now provides 100 places for 175 students in open admission institutions, and 100 places for 63 students in the limited admission institutions, due to their rigorous selection policy in the latter system (CSEFRS, 2014, p.27). Moreover, the cost per student in those institutions is three times higher than the cost per student in open admission institutions, and the rates of academic supervision are also better (CSEFRS, 2014, pp.19-20).

\subsubsection{Challenge of academic tutoring}

Indeed, tutoring as 'a tool for democratisation and equity for the most modest students is an important means of improving the internal achievement of the university' (Zouaoui, 2005, p.192). However, in the absence of a clear definition and firm regulation of this type of support, tutoring has often been confused with psychological support and presented in some universities as 'psychosocial tutoring' (e.g. Charte du tutorat, 2013). Volunteer master's and doctoral students who are required to listen and help the students with personal difficulties are usually unqualified for conducting psychosocial support.

Furthermore, the students' personal difficulties require an in-depth exploration of the emotional aspect that cannot be handled by a tutor; they require the intervention of trained psychosocial professionals (Ender \& Newton, 2000, Bettinger \& Baker, 2011, Whitmore, 2010). Despite all the goodwill, it would be difficult for untrained students to achieve a professional relationship that aims to raise the student's awareness to realize what is right for him or her to do at any given time (Basco \& Cote, 2010, p.90). Thus, tutoring as it is conceived in certain universities betrays a lack of understanding as to the two very distinct social structures needed: academic 'tutoring' and the psychosocial aspect of 'counseling'. 


\subsubsection{Challenge of dropout rates}

As far as the new pedagogical architecture is concerned, the 'Licence, Master, Doctorat' (LMD) system produced positive results right after its implementation. New fields of studies have been introduced at the university, and 2340 majors have been accredited (1376 in 2009-2010), (MENSRSFC, 2014, p.10). Graduation rates increased during the period 2001-2012 and more particularly in 2005-2006 due to the graduation both of the first cohorts of students majoring under the LMD system and others from the previous cycle system (CSEFRS, 2014, p .102).

However, in terms of university student attrition, the latest study carried out by the Higher Council for Education shows that 64 per cent leave university without a diploma, 25.2 per cent of which in the first year, 40.2 per cent after two years of study, and 20.9 per cent after three years in university. The remaining students who 'cling' to studies spend up to 6 consecutive years in the system without graduating. 68 per cent of dropouts occur in the Faculties of Law, Economics and Social Sciences, which also have the lowest graduation rates, followed by the Faculties of Sciences, and the Faculties of Letters and Human Sciences (CSEFRS, 2014, p.103), thus aggravating the open admission system's depreciation

(......) Considered by the baccalaureate holders as residual education which receives all those who did not have the chance to integrate in the limited admission system, reputed to be inadequate in the labor market by companies, overloaded by the 'massification' of the student population, and struck by a negative image in society, education in the open admission system crystallizes the problems of quality. (CSEFRS, 2014, p.103).

\subsubsection{Failure of the Emergency Plan}

An evaluation of the education system was recommended in the National Charter of Education and Training (NCET, art. 157), and was reinforced in the country's Constitution (2011, art.168), which enshrines good governance and accountability as fundamental principles for the functioning of the education system (Royaume du Maroc, 2011). To this end, four years after the implementation of the Emergency Plan, the National Authority of Evaluation (NAE), an organ of the Higher Council for Education, conducted an assessment of the Moroccan education system since the NCET came into force in 2000. In its analytical report, the NAE noted several recurring dysfunctions in the Moroccan education system (CSEFRS, 2014).

Further to the NAE's report, the education system was once again highly decried at the highest level of the State. The Royal Speech of $20^{\text {th }}$ August, 2013 was devoted entirely to the education sector. His Majesty the King laid bare all the inadequacies relating to governance and pedagogy, and urged decision-makers to decide on the issue of the language of instruction in secondary education, as well as the obsolete majors which make universities 'factories of unemployed graduates'. His Majesty clearly specified that Morocco needed manpower oriented towards global job markets, and it was therefore necessary to orient students towards 'vocational' majors. His Majesty the King also deplored the intrusion of politics into the field of education, reminding the government of its duty to consolidate and build on the positive achievements of the NCET and the Emergency Plan initiated by the previous governments because it 'it is unreasonable that every five years, each new government comes up with a new plan, ignoring previous ones, knowing that no government is able to implement its own fully, given the short term of its office' (Royal Speech, 2013, p.3).

For the aforementioned reasons, His Majesty asserted the necessity of a 'halt for an objective examination of conscience in order to evaluate the achievements and to identify the existing weaknesses and dysfunctions' (Royal Speech, 2013, p.3). The education sector must remain far from political outbidding and rivalries, because, besides its societal, economic and cultural mission, 'it has the mission of ensuring the education and the upgrading of human resources to enhance their integration into the dynamic development process, and this through the implementation of an efficient educational system' (p.3).

Indeed, the intrusion of politics into education is one of the main reasons for the failure of the 1999 reform. The NCET should have been approached in its entirety as a comprehensive reform of a societal educational project at all levels of education. However, consecutive governments have envisaged the NCET as a sectoral reform and each one has tackled it from a specific angle and implemented education actions according to its own vision. As a result, the NCET incurred 'the effects of the partisan battles where short-sighted cyclical choices, without reflection and serious analysis of their impacts and consequences, have overridden academic and pedagogical criteria' (Zouaoui, 2005, p.175), which 'does not fail to disorient the planners of the sector' (p.181).

Undeniably, the major educational reforms undertaken since 1999 through the NCETand the Emergency Plan had allowed for significant progress and had overcome the challenge of quantity by providing massive access to universities. However, the reforms had not helped in overcoming the challenge of quality. Consequently, the previous achievements needed 'new breath to be reinforced, reactivated and enriched so that innovative solutions could be proposed in view of favoring the establishment of a School of Equity, Quality and Promotion' (CSEFRS, 2015, p.17). This 'new breath' has been sought in the recommendations of the latest Strategic Vision of Reform 2015-2030.

\section{Strategic Vision of Reform 2015-2030}

To revitalize the education sector, a Strategic Vision of Reform (2015-2030) was presented by the Higher Council for Education with the purpose of consolidating the achievements realised by the NCET and the Emergency Plan, and proposing new projects. It aims to establish a new 'school' based on three foundations that carry its societal project: 
'equity and equal opportunity; quality for all; the promotion of individuals and society'. This reform is intended to be comprehensive, and the term 'school' refers to all the components of the education system, pre-school, primary, secondary, secondary vocational, higher education, scientific research, staff training, vocational training and traditional education' (CSEFRS, 2015, pp. 93).

The reform confirms that education suffers from early dropouts, and admission capacity in vocational training is below social demand (CSEFRS, 2015, p.16). Therefore, reducing attrition should be one of the fundamental principles of achieving equity and equality in education. In addition to the major pedagogical recommendations already stated in previous reforms, this new reform strongly recommends the 'Edification of a civic, democratic and egalitarian society' (Lever 18) through the establishment of educational structures which allow students to develop 'democratic and civic practices' within their institutions. This is innovative as it is suggested to involve students in the management of their institution, and set up mediation mechanisms to help them deal with their stress and conflict management (CSEFRS, 2015 , p.69). This recommendation is indeed very relevant to student attrition in the sense that engaging students in their institution can enhance their sense of belonging to their institution and ultimately lead to their persistence and degree completion (Chu, 2016; Pascarella \& Terenzini, 2005; Strayhorn, Travers, Tillman-Kelly, 2015; Tinto, 1993).

Furthermore, the 2015-2030 reform considers psychosocial support at the university one of the most important pillars of student retention. For the first time, the establishment of a 'psychosocial mechanism for the benefit of learners who need it' (CSEFRS, 2015, p.93) is clearly expressed at an institutional level and strongly recommended through the creation of 'counselling centers for pupils, students and trainees' (p.69). Of course, this recommendation is not new, as counselling centers already exist in some primary and high schools. However, they seldom exist in public universities, unlike private universities, which now make psychosocial support their best comparative advantage, and even the 'secret' of student retention (Vincent Tinto, 2006). They could not be closer to the truth, 'because [as] their public evolves, the universities must in turn adapt to a more important heterogeneity. New missions of admission, information and support to students appear' (Basco \& Cote, 2010, p.16).

Evidently, it is too early to comment on the successes and failures of the Strategic Vision of Reform as it is only in its second year and not yet binding by any law. However, based on prior experience in the Emergency Plan, we can predict that if universities do not define the students' support service clearly, and if its implementation is neither institutionalized nor regulated, it is likely to become a project that will never emerge, or a project that will depend on the vision of its voluntary initiators within universities as it has been the case for the tutoring adopted in some universities. Following on from this, this latest reform could be the opportunity to set up institutional student support services in partnership with professionals who not only help students solve problems but help them construct their professional as well as their life projects (Braxton, 2000; Evans, Forney, Guido, Patton, \& Renn, 2009; Seidman, 2012, Tinto, 2015, Whitmore, 2010).

\section{Conclusion}

In spite of the fact that progress is perceptible in terms of students' access to university, grants, accommodation, food services, health coverage, and pedagogical architecture; most efforts made since the implementation of the higher education reforms in 1999 have been invested in increasing the quantity of institutions and the number of student enrolments. This quantitative progress is vital but it has taken over qualitative progress and has not prevented student attrition from increasing.

Indeed, student departure from university is a complex phenomenon because the decision to leave studies occurs for a plethora of reasons that may be affecting students long before matriculation or right after matriculation at the university. Therefore, it is utopian to believe that the reforms can eradicate attrition from universities as it is impossible for them to control all the factors that cause students to interrupt their studies, whether temporarily or permanently. Nevertheless, it is necessary for institutions to understand the causes of attrition and seek the most appropriate means of reducing it.

As no empirical research has so far covered the attrition phenomenon in higher education, unlike in the primary and secondary education, it is recommended that an empirical investigation of this phenomenon be undertaken from different perspectives, namely that of the students, the institutions, the higher education policymakers, and any other stakeholders. Empirical research is needed not only to identify the factors that lead students to be at risk of dropping out of university, but also to understand the factors that help successful students to persist at university. Both parts of the investigation could provide some guiding framework for universities in their efforts to retain students.

Finally, knowing that student attrition rates increase the average cost of education and have drastic effects on the student, on the family, and on society as a whole, it would be useful for universities to explore all the potential means of intervention likely to reduce this cost and help students persist until degree completion. To this purpose, it is necessary to provide effective support to students by combining institutional, pedagogical, sociological and psychological means able to improve their persistence in university until graduation and by extension, to improve their quality citizenship for the benefit of society. 
References

Banque Mondiale. (2007). Se soustraire à la pauvreté au Maroc, Réduction de la pauvreté et Gestion économique. Retrieved from goo.gl/uLurWf

Banque Mondiale. (2008). Un parcours non encore achevé : la réforme de l'éducation au Moyen-Orient et en Afrique du Nord, Rapport sur le développement de la région MENA, Résumé analytique. Washington.

Basco, L., \& Cote, F. (2010). Accompagner l'étudiant: de la connaissance de soi à la construction de la personne. Chronique sociale.

Bettinger, E., \& Baker, R. (2011). The effects of student coaching in college: An evaluation of a randomized experiment in student mentoring (No. w16881). National Bureau of Economic Research. Retrieved from https://core.ac.uk/download/files/153/6529168.pdf

Braxton, J. M. (2000). Reworking the student departure puzzle. Vanderbilt University Press.

Charte du tutorat. (2013). Université Ibn Zohr. Retrieved from http://www.flsh-agadir.ac.ma/wpcontent/uploads/2013/03/Charte_Tutorat.pdf

Chu, Z. (2016). The First Year Experience on an Urban Campus: A Case Study Exploring the Impact of First Year Programs on Student Perceptions of Belonging, Adjustment, Success, and Support. Retrieved from goo.gl/JU6e1u

CSEFRS. (2008). Rapport analytique (2008). Etat et perspective de système d'éducation et de formation. Volume 2. Instance Nationale d'Evaluation du Système d'Education, de Formation et de Recherche Scientifique. Retrieved from goo.gl/hfR1Tg

CSEFR. (2014). Rapport analytique. La mise en æuvre de la Charte Nationale d'Education et de Formation 20002013. Acquis, déficits et défis. Retrieved from goo.gl/JGAAXH

CSEFR. (2015). Vision stratégique de la réforme 2015-2030. Pour une école de l'équité, de la qualité et de la promotion. Retrieved from http://www.csefrs.ma/pdf/Vision_VF_Fr.pdf

Ender, S. C., \& Newton, F. B. (2000). Students Helping Students: A Guide for Peer Educators on College Campuses. The Jossey-Bass Higher and Adult Education Series. Jossey Bass Publishers, 350 Sansome St., San Francisco, CA 94104.

Evans, N. J., Forney, D. S., Guido, F. M., Patton, L. D., \& Renn, K. A. (2009).Student development in college: Theory, research, and practice. Second edition. John Wiley \& Sons.

Lamrini, R. (2007). L'université Marocaine autrement. A world class university essai. Editions Marsam.

MENESFCRS. (2006). Département de l'Enseignent Supérieur. Assurance qualité dans la réforme de l'enseignement supérieur au Maroc. Rapport présenté à l'occasion de la Conférence sur la Qualité et 1'’Evaluation de l'Enseignement Supérieur, 18 au juin, 2006, CIEP, Sèvres, France. Retrieved from goo.g1/UsJ91ucontent_copy

MENESFCRS. (2008). Pour un nouveau souffle de la réforme de l'Education-Formation. Présentation du Programme NAJAH. Rapport détaillé - Version projet Juin 2008. Retrieved from goo.g1/WMn0OV

MENESFCRS. (2009). Programme d'urgence (2009-2012).17 Contrats pour le développement de l'université marocaine.

MENESFCRS. (2011). Programme d'urgence 2009-2012. Principales mesures prévues et éléments de bilan à miparcours 2008-2009- mai 2011. Retrieved from goo.gl/1Hj3h6

MENESFCRS. (2014). Système d'enseignement supérieur marocain. Retrieved from goo.gl/jLcPm3content_copy

Pascarella, E. T., \& Terenzini, P. T. (2005). How college affects students. (Vol. 2). K. A. Feldman (Ed.). San Francisco, CA: Jossey-Bass.

NCET (1999). Charte Nationale d'Education et de Formation. Royaume du Maroc. Commission Spéciale Education Formation. Retrieved from www.dfc.gov.ma

PNUD. (2007). La lutte contre le changement climatique: un impératif de solidarité humaine dans un monde divisé. Rapport mondial sur le développement humain 2007/2008.

Rapport général. (2005). 50 ans de développement humain et perspectives 2025. Retrieved from http://www.minculture.gov.ma/fr/images/stories/pdf/rg-fr.pdf

Royal speech. (30 July, 2000). Discours et Interviews de Sa Majesté le Roi Mohammed VI. Retrieved from http://www.aua.ma/files/pdf/lois/Discours\%20HUPV.pdf

Royal speech. (30 July, 2003). Discours et Interviews de Sa Majesté le Roi Mohammed VI. Retrieved from http://www.aua.ma/files/pdf/lois/Discours\%20HUPV.pdf

Royal speech. (2007). Ouverture de la première session de la première année législative de la huitième législature. Discours et Interviews de Sa Majesté le Roi Mohammed VI. Retrieved from http://www.aua.ma/files/pdf/lois/Discours\%20HUPV.pdf 
Royal speech. (20 th August, 2013). Retrieved from goo.gl/B5IAe3content_copy

Royaume du Maroc (2011). La Constitution. Edition 2011. Documentation juridique Marocaine. Retrieved from goo.g1/IpOgB9content_copy

Seidman, A. (ED). (2012). College student retention: Formula for student success. $2^{\text {nd }}$ edition. Rowman \& Littlefield Publishers, Inc.

Strayhorn, T. L., Lo, M. T., Travers, C. S., \& Tillman-Kelly, D. L. (2015). Assessing the relationship between wellbeing, sense of belonging, and confidence in the transition to college for Black male collegians. Spectrum: A Journal on Black Men, 4(1), 127-138.

Tinto, V. (1993). Leaving college: Rethinking the causes and cures of student attrition. University of Chicago Press, $5801 \mathrm{~S}$.

Tinto, V. (2006). Student retention. What next? Retrieved from goo.gl/bFnW7r

Tinto, V. (2015). Through the Eyes of Students. Journal of College Student Retention: Research, Theory \& Practice. DOI: $10.1177 / 1521025115621917$

UNESCO. (2015). Rapport mondial de suivi sur l'EPT. Education pour tous 2000-2015: Progrès et Enjeux. Retrieved from goo.gl/cgkx10

Whitmore, J. (2010). Coaching for performance: growing human potential and purpose: the principles and practice of coaching and leadership. Nicholas brealey publishing.

World Economic Forum. (2016). The human capital report 2016. World Economic Forum, Geneva, Switzerland. Retrieved from goo.gl/Tr3vZOcontent_copy

Zouaoui, M. (2005). L'enseignement supérieur depuis l'indépendance: la dégradation de la qualité était-elle inéluctable? Retrieved from goo.gl/s13tZB 